\title{
PHILOSOPHICAL AND RELIGIOUS STUDIES
}

DOI: 10.46340/ephd.2020.6.1.21

Ярослав Гнатюк, к. філос. н.

Прикарпатський національний університет імені Василя Стефраника, Україна

\section{ПАРАДИГМАЛЬНІ МЕТОДОЛОГІЧНІ МОЖЛИВОСТІ ІСТОРИКО-ФІЛОСОФСЬКОЇ НАУКИ}

\author{
Yaroslav Hnatiuk, PhD in Philosophy \\ ORCID ID: https://orcid.org/0000-0003-1340-1922 \\ Vasyl Stefanyk Precarpathian National University, Ukraine

\section{PARADIGMATIC METHODOLOGICAL POSSIBILITIES OF HISTORICAL AND PHILOSOPHICAL SCIENCE}

\begin{abstract}
The article is devoted to the study of paradigmatic methodological possibilities of the history of philosophy as part of humanities. Paradigmatic methodological possibilities are considered by the example of the history of Western logic and metaphysics, which are closely interconnected. In the course of historical and philosophical analysis, the fundamental concept of "paradigm" is elaborated through the concepts of "paradigm in the history of philosophy", "paradigm in logic" and "paradigm in metaphysics". Among the paradigms of Western formal and informal logic are three basic ones: the naturalistic paradigm of logic, the transcendental paradigm of logic, and the analytical paradigm of logic. The paradigms of Western metaphysics are grouped into three main groups: the ontology metaphysics paradigm, the epistemology ontology paradigm, and the ontognoseology metaphysics paradigm. Their communicative potential is explored in the context of the methodology of historical-philosophical intercultural communication.

Keywords: naturalistic paradigm of logic, transcendental paradigm of logic, analytical paradigm of logic, paradigms of metaphysics of ontology, paradigms of ontology of epistemology, paradigms of metaphysics of ontognoseology.
\end{abstract}

Однією зі стратегій методології історико-філософської міжкультурної комунікації як інформаційної взаємодії дослідницької і досліджуваної філософсько-методологічних культур $є$ історія філософської дисципліни. Вона припасовує парадигмальний підхід до царини історикофілософських досліджень.

Парадигма в контексті історико-філософського дослідження, за В. Ярошовцем, - це «передусім підстава виявлення загального в унікальному. Це комунікативне довкілля автора, сукупність непроблематичних очевидностей, що імпліцитно репрезентовані в його творах. Це дійсність конкретно-історичного наукового дискурсу і боротьби між філософськими вченнями, теоріями та концепціями. Це підстава історико-філософських узагальнень, завдяки яким доречно говорити про цілісність історії філософії, зв'язок і спадковість між творчими зусиллями мислителів минулого та сучасності» ${ }^{1}$.

Проаналізуємо парадигмальний підхід до історії філософських дисциплін на прикладі історії логіки та історії метафізики. Парадигма в логіці - це сукупність спільних для наукового товариства теоретичних поглядів, що вживаються як стандарт, або модель для наукового дослідження ${ }^{2}$. В історії логіки як науки можна виокремити три наукові парадигми: натуралістичну, трансцендентальну й аналітичну. Натуралістична парадигма логіки виникла в античності й стала пануючою у Середні віки.

\footnotetext{
1 Ярошовець, В. (2010). Методологічгна рефлексія історико-філософського процесу. Психологія і суспільство, $1,67$.

${ }^{2}$ Цалін, С. Д. (2006). Логічний словник-довідник. Харків: Факт, 236. 
Такий стан справ, завдяки авторитету Аристотеля, зберігався аж до Нового часу. Її репрезентують діалектика Платона, логіка Аристотеля, логіка стоїків та схоластична логіка.

Логіка Аристотеля побудована на біологічній аналогії і природній мові. Вона розглядає міркування людей як логічні організми та описує їх типи засобами природної мови, за аналогією із видами тварин та формами їхніх органів. Про біологічну аналогію як основу логіки Аристотеля першим заговорив Г. Гегель. Він зазначав, що «подібно до того, як у природній історії розглядаються та описуються тварини, наприклад, носоріг, мамонт, якийсь вид жуків, молюски і т.д., так i Аристотель $є$ ніби природоописувачем цих духовних форм мислення. Але в цьому умовиводі від одного до іншого Аристотель насправді зобразив мислення в його лише скінченному застосуванні; його логіка $\epsilon$ тому природна історія скінченного мислення» ${ }^{1}$.

Трансцендентальна парадигма логіки склалася в Новий час у Німеччині. Ї̈̈ репрезентують універсальна характеристика Г. Ляйбниця, трансцендентальна логіка I. Канта, діалектична логіка Г. Гегеля, марксистська і немарксистська діалектика. Завдяки діяльності Г. Гегеля, й особливо його учня К. Маркса, діалектична логіка стала популярною, а трансцендентальна парадигма логіки пануючою у новітні часи.

Діалектична логіка, як і метафізична, побудована на біологічній аналогії та природній мові. Діалектична логіка розглядає міркування людей як логічні організми та описує їх типи засобами природної мови, за аналогією із видами рослин, що ростуть і розмножуються, генетично передають інформацію про себе. Цим діалектична логіка певною мірою схожа на метафізичну. Але між діалектичною i метафізичною логікою існують істотні відмінності. Метафізична логіка сконцентрована на зовнішній формі, «морфології тварин», діалектична - на внутрішній формі, «генетиці рослин».

Аналітична парадигма логіки з'явилася у новітні часи в Австрії. ІІї репрезентують мереологія С. Лєснєвського, логіка предикатів Г. Фреге, філософська логіка Г. фон Врігта, логічна семантика Р. Карнапа тощо.

Логіка предикатів Г. Фреге, що є знаковою для аналітичної філософії, і котру інколи називають постфрегіанською філософією та базовою для аналітичної парадигми логіки, побудована на фізичній аналогії і спеціальній штучній, формалізованій мові. Вона розглядає міркування людей як логічні речовини та описує їх типи засобами формалізованої мови, за аналогією з видами молекул, що складаються із комбінацій атомів, з якими співвідносяться складені й прості висловлювання. За В. Свєтловим, «фізики і хіміки стверджують, що будь-яка речовина складається з молекул, а молекули - з атомів. Аналогічно в традиційній логіці вважають, що умовивід (логічна речовина) складається із суджень (логічних молекул), судження - 3 понять (логічних атомів)» ${ }^{2}$. Така ж сама аналогія проводиться і в сучасній логіці, в тому числі й логіці предикатів.

Названі парадигми виокремлюються на підставі різного тлумачення завдань загальної семантики - тлумачення, яке мало місце в ту чи іншу історичну епоху, було пов'язане з відповідним соціокультурним контекстом. У натуралістичній парадигмі логіки як неформальна семантична модель, що реалізує логічні формалізми, функціонував універсум природної чи натуральної мови, причому такий, що повинен був слугувати цілям практичного законодавства ${ }^{3}$. У трансцендентальній парадигмі логіки універсум натуральної мови також розглядався як реалізуюча неформальна семантична модель, але не з перспективи практичного законодавства, а в межах теоретичного опису всіх спостережуваних феноменів ${ }^{4}$. В аналітичній парадигмі логіки та чи інша ефективно побудована формальна семантична модель постає реалізуючою моделлю універсуму штучної, формалізованої мови ${ }^{5}$. Якщо неформальні семантичні моделі натуралістичної і трансцендентальної парадигми логіки передбачали наявність якихось метафізичних референтів - «Ідея», «Форма», «Дух» і подібних до них, то формальна семантична модель аналітичної парадигми логіки бере до уваги лише цільові проекції індивіда, що відповідають конкретним фізичним референтам ${ }^{6}$. Якщо в межах натуралістичної парадигми логіки досліджувалась аналітична істина, розроблялась онтологія Логосу як система принципів або законів логіки, фізики та етики, що керують Космосом, принизують його макро- і мікросвіти, то в рамках

${ }^{1}$ Гегель, Г. В. Ф. (1994). Лекиии по истории философии. Санкт-Петербург: Наука, 2, 285.

${ }^{2}$ Светлов, В. А. (2011). Логика. Санкт-Петербург: Питер, 31.

${ }^{3}$ Шуман, А. Н. (2001). Философская логика: Истоки и эволючия. Минск: Экономпресс, 7.

${ }^{4}$ Там само, 8 .

${ }^{5}$ Там само.

${ }^{6}$ Там само, 11. 
трансцендентальної парадигми логіки більшу увагу приділяли синтетичній істині, Суб’єкту-Субстанції, Логосу як єдності логіки, онтології та гносеології. А в аналітичній парадигмі логіки відбувся семантичний поворот до аналітичної істини як завжди істинної формули в логічно можливих світах.

Натуралістична, трансцендентальна й аналітична парадигма логіки узагальнюються в натуралістичній, трансцендентальній та аналітичній логіці. Натуралістична логіка скерована на світ природи, трансцендентальна - на світ досвіду, аналітична - на світ мови.

Історія логіки щільно пов'язана з історією метафізики. На думку Ф. Ажімова, «якщо метафізичне - раціонально пізнаване, мислиме, то воно імпліцитно перебуває у сфері логічного та

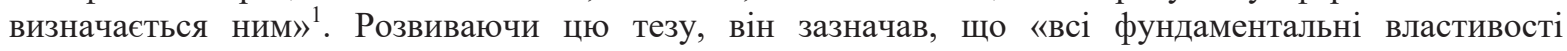
метафізики, іiі абстракції, структури і референції щільно пов'язані з логікою і уможливлюють будьяку наукову теорію. Не існує більше логіки без онтології через те, що абстрактні теорії завжди пов'язані з метафізикою»². Отже, мова логіки зумовлена онтологічними об'єктами, а онтологічні припущення зазвичай $€$ продовженням логічних постулатів, наслідками логічних виводів та обгрунтувань, результатами дедуктивного чи індуктивного способів побудови метафізичної теорії.

Парадигма в метафізиці - це одна понятєєва структура, яка намагається надати єдиної форми тим результатам, які, з одного боку, достатньо нові для того, щоб сформувати одну стабільну групу послідовників, а з іншого - достатньо відкриті, щоб залишити цю групу в ситуації розв'язання різноманітних проблем³. В історії метафізики можна виокремити низку іï типів. Це метафізика онтології, метафізика гносеології і метафізика онтогносеології. Метафізику онтології представляє парменідівська, платонівська, аристотелівська, августинівська і томістична парадигми, метафізику гносеології - декартівська, спінозівська та ляйбницівська парадигми, метафізику онтогносеології кантівська і гайдегерівська парадигми.

Парменідівська парадигма - це парадигма метафізики буття. Парменід сформулював такі важливі принципи метафізики як принцип тотожності й несуперечливості та їі головне поняття поняття буття. Виходячи 3 принципу тотожності, він висунув тезу про єдність буття. Існування небуття відкидалося ${ }^{4}$.

Платонівська парадигма - це парадигма метафізики буття і небуття. Вона викладена в його метафізичній теорії двох світів: світу сутності та світу виникнення, світу Ідей і світу речей. За Платоном, світ Ідей постає першопочатковою реальністю, а світ речей- другою, вторинною реальністю. Друга реальність - лише вияв першої, ії відображення, наслідування, імітація. Містком, який пов'язує два рівні, слугує принцип участі. Відповідно до нього, чуттєвий світ бере участь в інтелігібельному світі ${ }^{5}$. На думку Платона, Ідеї існують у собі та для себе, в ієрархічній формі й становлять справжнє буття. На вершині світу Ідей перебуває ідея Блага, що збігається з Єдиним, де Єдине - принцип буття, істинності й цінності. Речі ж народжуються 3 поєднання формального принципу Єдиного з матеріальним принципом Діади. Світ Ідей - причина світу речей 6 .

Аристотелева парадигма обгрунтовує метафізику як онто-теологію. Звідси два аспекти метафізики. 3 одного боку, вона - наука про сутнє як сутнє, тобто універсальне вчення про буття як сукупна наука, з іншого - наука про Божественну пра-основу всього сутнього, вчення про Бога ${ }^{7}$ У метафізиці Аристотель синтезував традиції всіх попередніх філософів і філософських шкіл античності, окресливши чотири головні напрями: дослідження першопричин, або найвищих первнів, пізнання буття як такого, наука про субстанції та осягнення Божественної надчуттєвої субстанції ${ }^{8}$.

Метафізика Аристотеля суттєво відрізняється від метафізики Платона. Оскільки метафізика Аристотеля - це онто-телеологія, вона відрізняється від метафізики Платона як в онтологічному, так

\footnotetext{
${ }^{1}$ Ажимов, Ф. Е. (2007). Онтолого-метафизические проекты современной западноевропейской философии.

Вопросы философии, 9, 146.

2 Там само, 147.

${ }^{3}$ Мондін, Б. (2010). Онтологія і метафізика. Жовква: Місіонер, 20.

${ }^{4}$ Там само, 21.

5 там само, 22.

${ }^{6}$ Гусева, Т. Л. (2010). Очерк истории метафизики: от Платона до «докритического» Канта. Философские науки, 4, 151-152.

${ }^{7}$ Корет, Э. (1998). Основы метафизики. Киев: Тандем, 13.

${ }^{8}$ Гусева, Т. Л. (2010). Очерк истории метафизики: от Платона до «докритического» Канта. Философские науки, 4, 153-154.
} 
і телеологічному плані. У своїй онтології Аристотель протиставив Ідеям Платона форму і матерію. Форма і матерія як остаточні причини і найперші принципи будь-якого буття постають в Аристотеля онтологічними проекціями сутності як єдності загального й одиничного. Реалізацію потенційної можливості матерії набувати форми Аристотель називав ентелехією. Форма цю можливість актуалізує, матерія ж поєдную потенцію й акт ${ }^{1}$. У Платона мостами, які пов'язують Ідеї з речами, основи $з$ явищами - це участь та імітація. Аристотель замінив їх іншими двома мостами: телеологією і кореляцією акту-потенції. У Платона телеологія трансцендентна, в Аристотеля ж вона - іманентна, органічно притаманна самим речам.

За Аристотелем, телеологія супроводжує становлення і надає йому смисл. Становлення - це рух, а його кінцева мета - Бог, Нерухомий Рушій. Бог Аристотеля - пряма протилежність першоматерії. Якщо вона повністю позбавлена форми, гранично пасивна, то Бог - цілком духовна істота, що концентрує в собі все розмаїття форм, позбавлених матеріальних субстратів.

Не будучи творцем світу, Бог Аристотеля наділений функцією Першорушія, без чого не могли б здійснюватися численні процеси формоутворень у природно-людському світі. При цьому БогНерухомий Рушій.

За вченням Аристотеля, кореляція акту-потенції суттєва для структури матеріальної субстанції, в якій матерія постає потенцією, а форма спричиняє акт. Це така кореляція, яка вказує на недосконалість, оскільки несе обмеження акту з боку потенції, й тому перевищується, утворюючи субстанції, що складаються з акту і потенції в субстанції, що є чистим актом найпростішої форми. У такий спосіб по-новому досягається мета - Первень, Бог, Нерухомий Рушій².

Августинівська парадигма - це метафізика внутрішнього буття. Метод дослідження внутрішнього буття Августин формулював так: вивчай себе самого, запитуй себе самого і знайдеш відповідь у глибині власного сумління. Він обгрунтовував його, наводячи у вигляді аргументу себе самого як суб'єкта істини. Августин не будував своєї метафізики ні на Бутті, ні на Ідеї чи Субстанції, а побудував іiі на Істині. Вона у нього не супроводжує Єдине чи Слово, а збігається з Сдиним i Словом. Після обгрунтування методу Августин уточнив принцип участі. Він привніс у розуміння цього принципу новий зміст. Якщо у Платона участь грунтується на подібності між копіями і зразком, у Плотіна - на еманації, у процесі якої, висловлюючись метафорично, «канали беруть воду 3 джерела», то в Августина участь стає участю для сотворення ${ }^{3}$.

Томістська парадигма - це метафізична парадигма створеного буття. Метафізика для Томи Аквінського, як і для Аристотеля, також онто-теологія ${ }^{4}$. Однак він вніс в аристотелівську парадигму суттєве уточнення. Якщо Аристотель говорив про органістичну метафізику, то Тома Аквінський вів мову про креаціоністсько-органістичну метафізику. Таке уточнення спричинило певні важливі зміни. Перша зміна полягала в тому, що поняття буття, яке вже не сприймалось у слабкому значенні, як найзагальніше для всіх речей, трактувалось як найвища досконалість, досконале буття, що перевершує всі сутності, субстанції і форми.

Друга зміна стосується внутрішньої структури скінченого сутнього, яка, крім фізичної композиції матерії і форми, також включає метафізичну композиції сутності та існування, тобто акту буття. Метафізична композиція єдина. Вона зустрічається в ангелів, які будучи чистими духами, не знають композиції матерії та форми.

Третя зміна стосується переоцінки пріоритетних шляхів у процесі сходження від істот до Буття, яке в оригінальній томістичній парадигмі проходить онтологічні шляхи більше, ніж богословські чи космологічні, як у парадигмі Аристотеля. Це шляхи композиції сутності та акту буття, участі скінчених істот у досконалості буття, відповідно до ієрархії рівнів буття, де досконалість буття істоти осягають щодо різних рівнів ${ }^{5}$.

Шлях до метафізичної предметності розумівся Томою Аквінським як інтелектуальне сходження до дедалі вищого рівня абстракції: від абстракції фізичної до математичної, а від неї до абстракції метафізичної 6 .

\footnotetext{
${ }^{1}$ Там само, 154.

${ }^{2}$ Мондін, Б. (2010). Онтологія і метафізика. Жовква: Місіонер, 25.

${ }^{3}$ Там само, 28-29.

${ }^{4}$ Корет, Э. (1998). Основы метафизики. Киев.: Тандем, 14.

${ }^{5}$ Мондін, Б. (2010). Онтологія і метафізика. Жовква: Місіонер, 30.

${ }^{6}$ Бахтин, М. М. (1979). Эстетика словесного творчества. Москва: Искусство, 157.
} 
Якщо в добу Античності й Середньовіччя метафізика була метафізикою буття, то в Новий час вона трансформувалась у метафізику пізнання ${ }^{1}$. Метафізику пізнання у Новий час репрезентують декартівська, спінозівська і ляйбницівська парадигми.

Декартівська парадигма визначила як первинний об'єкт філософського міркування не буття, а пізнання, суб'єкт, який пізнає, а не пізнаний об'єкт, Я, а не світ. Тому в ній метафізика стає повністю підпорядкованою гносеології․ Для Р. Декарта загальна метафізика - не онтологія, а гносеологія ${ }^{3}$. Гносеологічна метафізика Р. Декарта дуалістична. Максимально узагальнені головні категорії цієї метафізики редукуються до твердження, яке припускає існування лише двох, прямо протилежних субстанцій. Одна з них - матеріальна. Ї̈̈ атрибут - протяжність. Інша субстанція - духовна. Її єдиний атрибут - мислення. Душа постійно, в принципі, безперервно мислить ${ }^{4}$. Р. Декарт прийшов до своєї метафізики через запитання, як можливо осягнути щось у незалежній від мислення дійсності, якщо суб'єкту безпосередньо відомі завжди лише змісти уявлень. Відповідь випливала в межах його теорії досвіду, складниками якої є вчення про Я, матеріальну дійсність, Бога та відношення скінченого сутнього до Бога 5 .

Декартівська парадигма спочатку відкрила шлях суб’єктивізму, а потім - ідеалізму. Критерієм істини для Р. Декарта слугує очевидність, з якою об'єкт показується і вимагає суб'єкта. А оскільки очевидність зрозуміла, то суб'єкт не може їй відмовити. Декартівська метафізика - не іманентна, а трансцендентна, незважаючи на те, що вона рухається за маршрутом іманентності, оскільки виходить від суб'єкта, від Я, та йде в напрямі світу і Бога, точніше, спочатку Бога, а тоді світу. Вона відрізняється від класичної метафізики не пунктом прибуття - Нерухомий Рушій, Бог, а пунктом відправлення, яким $є$ вже не світ, фізична природа, а Я у своєму теоретичному вияві, мисляче Я. Тому це антропоцентрична, а не космоцентрична метафізика, якою була класична метафізика ${ }^{6}$.

Спінозівська парадигма відрізняється і від августинівської та томістської, і від декартівської парадигми тенденцією усувати протиставлення Бога і світу, духу і тіла, духовної і матеріальної субстанції ${ }^{7}$ Для Б. Спінози існує лише одна субстанція - Бог, а всі інші речі, які зазвичай позначають як субстанції, насправді є маніфестаціями субстанцій, їі модифікаціями, модусами, або станами субстанції.

Спінозівська парадигма - це нова версія неоплатонізму, але із вилученням усього довгого кортежу ієрархічних рівнів, які неоплатоніки помістили між Єдиним і матерією. Б. Спіноза наслідував неоплатонівську парадигму не тільки за змістом, предметно, а й також за методом. Він побудував усю свою філософську систему дедуктивно, аксіоматично і геометрично. Вся його побудова тримається на кількох дефініціях. Головні з них - визначення причини себе самого, скінченого атрибуту, способу буття Бога, свободи, вічності'.

Б. Спіноза - модерний метафізик, який надав метафізиці самостійного щодо богослов'я статусу та цілком заперечував ті уявлення, які Тора і Єванегліє мали про Бога. Як і неоплатоніки, Б. Спіноза поклав в основу всієї дійсності одиничний початок, який він ідентифікував із Субстанцією, а не з Єдиним. Підставою для цього став той факт, що тоді, коли Єдине перебуває поза будь-яким поняттям і визначенням, Субстанція, навпаки, цілком визначувальна через зрозумілі й виразні поняття ${ }^{10}$.

Ляйбницівська парадигма обстоює монадний плюралізм. Основними категоріями метафізики Г. Ляйбниця є дві категорії: субстанція і Бог, які пов'язані між собою. За Г. Ляйбницем, дійсність у своїй основі духовна. Він визнавав існування незліченної кількості духовних субстанцій, або монад. Монада - принцип субстанційної єдності та активності. Кожна монада пов'язана з усіма іншими

\footnotetext{
${ }^{1}$ Гусева, Т. Л. (2010). Очерк истории метафизики: от Платона до «докритического» Канта. Философские науки, 4, 157.

${ }^{2}$ Мондін, Б. (2010). Онтологія і метафізика. Жовква: Місіонер, 37.

3 Там само, 38.

${ }^{4}$ Соколов, В. В. (2009). Европейская философия XV-XVII веков. Москва: Академический Проект, 295.

${ }^{5}$ Рьод, В. (2009). Шлях філософї: з XVII по ХІХ століття. Київ: Дух і Літера, 34.

${ }^{6}$ Мондін, Б. (2010). Онтологія і метафізика. Жовква: Місіонер, 39-40.

${ }^{7}$ Рьод, В. (2009). Шлях філософії: з ХVII по ХІХ столітmя. Київ: Дух і Літера, 54.

${ }^{8}$ Там само, 55-56.

${ }^{9}$ Мондін, Б. (2010). Онтологія і метафізика. Жовква: Місіонер, 40.

${ }^{10}$ Мондін, Б. (2010). Онтологія і метафізика. Жовква: Місіонер, 41.
} 
монадами, але не реальними, причиновими зв'язками, а ідеальним відношенням, або відображенням. Кожна монада віддзеркалює в собі всі інші індивіди, або монади ${ }^{1}$. Своїм взаємним зв'язком монади завдячують Богові, який узгодив їх одну з одною. Для Г. Ляйбниця Бог- підстава наперед встановленої гармонії, що охоплює всі монади, тому зміни в одній із них супроводжуються змінами в усіх інших ${ }^{2}$.

Ляйбницева парадигма - це абсолютизована Платонівська система. Із двох світів Платона збережено тільки один - нематеріальний, інший - це чиста видимість. Щоб усунути будь-яку основу матеріалізму, Г. Ляйбниць заперечував саме існування матерії, а щоб усунути будь-яку основу емпіризму, він редукував усе до теорії вроджених ідей ${ }^{3}$.

Отримавши свій класичний вираз у системах Р. Декарта, Б. Спінози і Г. Ляйбниця, метафізика згодом пережила кризу, зумовлену відокремленням від неї низки наук, виродженням метафізичної теорії у догматичне систематизаторство, наприклад, в системі X. Вольфа, а також руйнівною критикою з боку скептицизму, сенсуалізму і механістичного матеріалізму Просвітництва ${ }^{4}$. Х. Вольф не створив нової метафізичної парадигми, але переформулював і консолідував ляйбницівську, реалізуючи могутній синтез між філософським дискурсом учителя і науковими відкриттями Нового часу $^{5}$. Його систематика, яка значною мірою увійшла у шкільну філософію Нового часу, розуміла під метафізикою сукупну теоретичну філософію на противагу етиці як практичній філософії. Х. Вольф поділив метафізику на загальну - онтологію як науку про сутнє як таке, і особливу, яка, своєю чергою, поділялася на три предметні сфери: космологію як учення про світ, психологію як учення про душу і теологію як учення про Бога. Перевага подібної концепції полягала у тому, що і природу, і людину вона прагнула зрозуміти метафізично, а вада її у тому, що вона настільки розділила вчення про буття і вчення про Бога, що загальна онтологія вже не бере до уваги остаточну підставу буття й, отже, перетворюється на формальне вчення про найперші поняття і принципи ${ }^{6}$.

Криза метафізики спричинила іiі критику. Кантівська парадигма- це критичний проект метафізики. На противагу трансцендентній метафізиці як ученню про взаємозв'язок світу досвіду з Першопринципом, що прагнула охарактеризувати реальність, яка перевищує межі чуттєвого досвіду, критична метафізика I. Канта як трансцендентальна філософія, або метафізика метафізики мала завдання окреслити найзагальніші особливості мислення та досвіду ${ }^{7}$. Отже, критична метафізика I. Канта замість трансцендентної метафізики пропонує трансцендентальну філософію як теорію досвіду. У трансцендентальній філософії І. Канта гносеологія та онтологія нерозривно пов'язані між собою ${ }^{8}$. Тому кантівська парадигма $€$ парадигмою метафізики як онтогносеології.

Своє завдання I. Кант бачив у зміні методу метафізики та визначенні сфери іï застосування. Розділивши розсуд і розум, він продемонстрував, що помилки трансцендентної метафізики породжуються некритичним поширенням діяльності розсуду за межі можливого досвіду. На переконання I. Канта, метафізика можлива як систематичне знання, дедуктивно виведене 3 чистого розуму. Однак він не побудував такої системи, обмежившись дослідженням суперечностей, в які неминуче впадає розум, коли намагається синтезувати завершену картину світу․

У І. Канта повторюються теми трансцендентної метафізики, але в іншому контексті. Бог і душа більше не вважаються предметами можливого пізнання, а розуміються як ідеї, яких вимагає мораль. У цьому розумінні практичному розумові притаманна першість перед теоретичним розумом ${ }^{10}$. Оскільки у І. Канта на першому місці перебуває практичне, у нього, по суті, була не метафізична

\footnotetext{
1 Там само, 43.

2 Рьод, В. (2009). Шлях філософії: з ХVII по ХІХ століття. Київ: Дух і Літера, 76.

${ }^{3}$ Мондін, Б. (2010). Онтологія і метафізика. Жовква: Місіонер, 44.

${ }^{4}$ Гусева, Т. Л. (2010). Очерк истории метафизики: от Платона до «докритического» Канта. Философские науки, 4, 157.

${ }^{5}$ Мондін, Б. (2010). Онтологія і метафізика. Жовква: Місіонер, 45.

${ }^{6}$ Корет, Э. (1998). Основы метафизики. Киев: Тандем, 15.

${ }^{7}$ Мондін Б. (2010). Онтологія і метафізика. Жовква: Місіонер, 18.

${ }^{8}$ Гусева Т. Л. (2010). Очерк истории метафизики: от Платона до «докритического» Канта. Философские науки, 4, 175.

${ }^{9}$ Гусева, Т. Л. (2010). Очерк истории метафизики: от Платона до «докритического» Канта. Философские науки, 4, 175 .

${ }^{10}$ Рьод, В. (2009). Шлях філософії: з XVII по ХІХ століття. Київ: Дух і Літера, 180.
} 
парадигма, а лише етична, яка стала підставою таких метафізичних постулатів, як свобода, безсмертя душі й Бог. Внаслідок цього метафізичне ціле було замкнене у світі, всередині людини, природи, історії, метафізичне ціле більше не утворювало двох світів, чуттєвого та інтелігібельного, а тільки один світ - світ людини ${ }^{1}$.

Кантівська деструкція метафізики, яку він здійснював на прикладі трьох складників спеціальної метафізики: спекулятивної психології, космології та теології, відкрила постметафізичному мисленню Європейського модерну нову перспективу. Стало очевидним, що будь-яка метафізика, яка абстрагується від фактичного досвіду і прагне піднятися до абсолютної та безумовної сутності, постаючи чистим Я, тотальним світом, або ідеалізованим Богом, може привести лише до уявних понять, уявних суджень та уявних проблем²

Якщо І. Кант мало цікавився онтологією, універсальною метафізикою, а більше уваги приділяв спеціальній метафізиці, таким ï напрямам, як спекулятивна психологія, космологія і теологія, то М. Гайдегер підвів метафізику до їі найважливішого завдання: до загальної онтології як учення про буття ${ }^{3}$. Якщо на першому етапі М. Гайдегер дотримувався аристотелівської парадигми і його метафізика була антропоцентричною, то на другому етапі він використав парменідівську парадигму і його метафізика стала онтоцентричною ${ }^{4}$.

Буття - все і з нього неможливо вийти. Але буття М. Гайдегера - це не статичне і нерухоме буття Парменіда, що виявляє себе у природі, а динамічне й мінливе, яке постає в історії5. Історія буття, за М. Гайдегером, відбувається як історія метафізики. Історія буття передусім означає, що сама метафізика $є$ лише однією історією буття, що, крім неї, існують інші первні інших історій. Один із таких первнів М. Гайдегер вбачав у передісторії метафізики, представленій Анаксимандром, Гераклітом і Парменідом ${ }^{6}$.

Проблематичною у гайдегерівській парадигмі є історизація онтології і водночас онтологізація історії. Для М. Гайдегера іншої онтології поза історичною епіфанізацією буття не існує, і навпаки, у своїй основі історія - це ніщо інше, як епіфанія буття. Така історизація буття веде до радикальної іманентності та до своєрідного онтологічного пантеїзму․․

Отже, метафізика, пройшовши у своєму розвитку такі головні етапи, як метафізика онтології, метафізика гносеології і метафізика онтогносеології, завершила відповідний цикл. Вона розпочала свій розвиток із парменідівської парадигми і закінчила гайдегерівською парадигмою з ії зверненням до поняття буття Парменіда. Остання велика парадигма метафізики поєдналася зії першою парадигмою.

\section{References:}

1. Azhimov, F. E. (2007). Ontologo-metafizicheskie proekty sovremennoj zapadnoevropejskoj filosofii. [Ontological and Metaphysical projects of Contemporary Western European Phylosophy]. Voprosy filosofii [Philosophical Questions], 9. [in Russian].

2. Bahtin, M. M. (1979). Jestetika slovesnogo tvorchestva [Estethic of verbal art]. Moscow: Iskusstvo. [in Russian].

3. Calin, S. D. (2006). Logichnij slovnik-dovidnik [Logical vocabulary handbook]. Kharkiv: Fakt. [in Ukrainian].

4. Tsyap, A. (translator) (2010). Filosofi. 60 portretiv [Phylosophers. 60 portraits]. Ternopil: Navchalna kniga-Bogdan. [in Ukrainian].

5. Gajer, M. (2007). Svit Kanta: Biografija [The world of Kant: Biography]. Kyiv: Junivers. [in Ukrainian].

6. Gegel, G. V. F. (1994). Lekcii po istorii filosofii [Lections on History of Phylosophy]. Saint Petersburg: Nauka, 2. [in Russian].

7. Guseva, T. L (2010). Ocherk istorii metafiziki: ot Platona do «dokriticheskogo» Kanta. [Study on History of metaphysics: from Plato to "precritical" Kant]. Filosofskie nauki [Philosophical Scienses], 4. [in Russian].

8. Jaroshovec, V. (2010). Metodologichgna refleksija istoriko-filosofskogo procesu [Methodological reflection of historical and phylosophycal process]. Psihologija i suspilstvo [Philosophy and Society], 1. [in Ukrainian].

9. Koret, Je. (1998). Osnovy metafiziki [The basics of Metaphysic]. Kyiv: Tandem. [in Russian].

10. Mondin, B. (2010). Ontologija i metafizika [Ontology and Metaphysics]. Zhovkva: Misioner. [in Ukrainian].

\footnotetext{
1 Там само, 46.

${ }^{2}$ Гаєр, М. (2007). Світ Канта: Біографія. Київ: Юніверс, 156-157.

${ }^{3}$ Мондін, Б. (2010). Онтологія і метафізика. Жовква: Місіонер, 51.

${ }^{4}$ там само, 52.

5 Там само, 52-53.

${ }^{6}$ Цяп, А. (перекл.) (2010). Філософи. 60 портретів. Тернопіль: Навчальна книга-Богдан, 85.

${ }^{7}$ Мондін, Б. (2010). Онтологія і метафізика. Жовква: Місіонер, 53.
} 
11. Rod, V. (2009). Shljah filosofii: z XVII-XIX stolittja [The way of Phylosophy: from XVII to XIX centuries]. Kyiv: Duh i Litera. [in Ukrainian].

12. Shuman, A. N. (2001). Filosofskaja logika: Istoki i jevoljucija [Phylosophycal logic: Origins and Evolution]. Minsk: Jekonompress. [in Russian].

13. Sokolov, V. V. (2009). Evropejskaja filosofija XV-XVII vekov [European philosophy XV-XVII cent]. Moscow: Akademicheskij Proekt. [in Russian].

14. Svetlov, V. A. (2011). Logika [Logic]. Saint Petersburg: Piter. [in Russian]. 